\title{
PENGARUH PEMBIAYAAN ULTRA MIKRO PT. PEGADAIAN CABANG PALU TERHADAP PERKEMBANGAN USAHA MIKRO KECIL DAN MENENGAH DI MASA PANDEMI COVID-19
}

\author{
Nur Wanita $^{1}$ Ryna Pratiwi $^{1}$ Nursyamsu $^{2}$ \\ 1,2,3 Jurusan Ekonomi Syariah, Fakulta Ekonomi dan Bisnis Islam, UIN Datokarama Palu, \\ Email nursyamsu@iainpalu.ac.id
}

\begin{abstract}
ABSTRAK
Penelitian ini bertujuan untuk menguji pengaruh pembiayaan Ultra Mikro (UMi) terhadap perkembangan usaha mikro kecil dan menengah (UMKM) PT. Pegadaian Cabang Palu di masa pandemi covid-19 periode tahun 2020. Jenis Penelitian ini adalah survey dengan pendekatan kuantitatif. Teknik penentuan sampel yang diigunakan adalah sampel jenuh, sebanyak 30 orang memperoleh pembiayaan Ultra Mikro di tahun 2020. Teknik pengumpulan data yang digunakan adalah wawancara, kuisioner dan dokumentasi. Untuk menganalisis data, digunakan beberapa tahap pegujian antara lain uji asumsi klasik, uji parsial (uji t), koefisien determinasi ( $R$ Square), dan regresi linear sederhana. Dari hasil uji t menunjukkan bahwa bahwa koefisien $t_{\text {hitung }}-0,331<t_{\text {tabel }} 12,706$ sehingga variabel independen tidak berpengaruh terhadap variabel dependen dan signifikansi bernilai 0,743 >0,05. Maka dapat disimpulkan bahwa variabel independen tidak memiliki pengaruh yang signifikan terhadap variabel dependen.
\end{abstract}

INFORMASI

ARTIKEL 


\section{PENDAHULUAN}

Usaha Mikro, Kecil dan Menengah (UMKM) memiliki peran penting dan strategis dalam pembangunan ekonomi nasional. Peranan UMKM yang begitu besar ditunjukkan dengan jumlah total unit usaha sebanyak 99\% dari usaha yang ada. Berdasarkan data dari Kementrian Koperasi dan UKM, tahun 2018 jumlah pelaku usaha di Indonesia sebesar 64.199.606. Dari jumlah tersebut UMKM sebanyak 64.194 .057 unit. $^{3}$

Untuk mendukung perkembangan UMKM, maka Pemerintah meluncurkan skema kredit program yang dikaitkan dengan tugas dan pembangunan ekonomi di sektor-sektor prioritas. Skema yang sudah ada sebelumnya masih menyisakan keterbatasan, khususnya dalam hal besaran kredit dan persyaratan. Pelaku UMKM mengalami kesulitan untuk mengakses skema ini yang disalurkan melalui lembaga keuangan bank. ${ }^{45}$ Untuk itu Pemerintah kembali melakukan terobosan dalam skema Kredit melalui Pembiayaan Ultra Mikro (UMi). Pembiayaan UMi merupakan tahap lanjutan dari program bantuan sosial kemandirian usaha yang menyasar pelaku UMKM yang belum bisa difasilitasi perbankan melalui

\footnotetext{
${ }^{3}$ Kementerian Koperasi dan UKM, Perkembangan Data Usaha Mikro, Kecil, Menengah (UMKM) dan Usaha Besar (UB) Tahun 2017-2018, http://www.depkop.go.id/uploads/laporan/15 80223129_PERKEMBANGAN\%20DATA\%20US AHA \%20MIKRO,\%20KECIL,\%20MENENGAH \%20(UMKM) \%20DAN\%20USAHA \%20BESAR\% 20(UB) \%20TAHUN\%202017\% 20-\% 202018.pdf, (20 Oktober 2020).

${ }^{4}$ Direktorat Jenderal Perbendaharaan, "Semangat UMi Wujudkan Pertumbuhan Ekonomi," Treasury Indonesia, Terbitan Pertama/2018, 8

5Ibid, 10.
}

program KUR.6Pembiayaan UMi ini hadir untuk menjadi pelengkap bagi skema KUR.

Salah satu lembaga keuangan Bukan Bank yang ditunjuk oleh pemerintah untuk menyalurkan pembiayaan ultra mikro adalah PT. Pegadaian.PT. Pegadaian (PERSERO) adalah salah satu Badan Usaha Milik Negara (BUMN) yang bergerak di sektor keuangan pada tiga lini bisnis yaitu pembiayaan emas dan aneka jasa. ${ }^{7}$ PT.Pegadaian (PERSERO) dan Pusat Investasi Pemerintah (PIP) menjalin kolaborasi untuk menyalurkan pembiayaan mikro kepada para pelaku UMKM. Dalam hal ini, PT. Pegadaian menyalurkan kredit dengan hukum gadai kepada masyarakat (terutama kalangan masyarakat kecil dan menengah). Untuk ikut membantu program pemerintah dalam upaya meningkatkan kesejahteraan dan bantuan modal usaha bagi pelaku UMKM, maka PT. Pegadaian menyalurkan pembiayaan Ultra Mikro (UMi).

Pembiayaan UMi termasuk dalam produk Kredit Usaha dengan Sistem Fidusia (KREASI) pegadaian. Kreasi adalah kredit dengan angsuran bulanan yang diberikan kepada Usaha Kecil dan Menengah (UKM) untuk pengembangan usaha dengan fidusia. Sistem fidusia berarti angunan untuk pinjaman cukup dengan BPKB sehingga kendaraan masih bisa digunakan untuk usaha.

6Kementerian Keuangan Republik Indonesia, "Pembiayaan Ultra Mikro (UMi)," Official Website Kementererian Keuangan Republik Indonesia, https://www.kemenkeu.go.id/umi (26 September 2020)

7Wikipedia, Pegadaian (Perusahaan)", Eksiklopedia Bebas, https://id.wikipedia.org/wiki/Pegadaian_(per usahaan) (02 November 2020) 
Keunggulan dari produk ini adalah sewa modal (bunga pinjaman) relatif murah dengan angsuran tetap per bulan, pinjaman mulai Rp. 1.000.000 Rp. 10.000.000, jangka waktu pinjaman fleksibel dengan pilihan jangka waktu 12, 18, 24, 36 bulan dan proses pencairan dana kredit hanya butuh 3 hari. ${ }^{8}$ Produk pembiayaan UMi dapat diperoleh di seluruh outlet Pegadaian di Indonesia, termasuk PT. Pegadain (PERSERO) di kota Palu.

Awal diluncurkan pada tahun 2017, produk pembiayaan Umi PT. Pegadaian Palu banyak diminati oleh masyarakat. karena kemudahan prosedur dan jaminan yang relatif terjangkau bagi pelaku UMKM. Namun demikian, sejak mewabahnya virus covid-19 di Indonesia dan ditetapkan sebagai pandemi pada tahun 2020, pemerintah mengkampanyekan kepada kepada masyarakat untuk melakukan Pembatasan Sosial Berskala Besar (PSPB) dan stay at home. Dengan adanya kebijakan tersebut, secara tidak langsung berdampak pada pelaku UMKM yang terbiasa berinteraksi secara langsung dengan pembeli atau pelaku usaha lainnya. ${ }^{9}$ Tidak terkecuali PT. Pegadaian Syariah Canbang Palu. Adanya kebijakan pemerintah tersebut menyebabkan sebagian pelaku usaha di berbagai sektor, terrmasuk pelaku UMKM terpaksa harus menerima kenyataan menurunnya jumlah

\footnotetext{
8PT. Pegadaian, "Pegadaian Pinjaman Usaha", Situs Resmi Pegadaian, https://www.pegadaian.co.id/produk/kreasi (30 Oktober 2020

9Sigit Irianto, Widyarini Indriasti Wardani dan Anik Tyaswati, "Harmonizing Rules Micro Small and Medium Enterprises In The Era of The Pandemic Covid19 in Indonesia, European Journal of Molecular \& Clinical Medicine-EJMCM, Vol.7 (September 2020), 642
}

permintaan barang maupun jasa dari konsumen/pelanggan, kesulitan memperoleh bahan baku serta kesulitan melunasi pinjaman. ${ }^{10}$ Dengan ditetapkannya kebijakan tersebut, mengurangi jumlah karyawan bahkan beberapa usaha terpaksa harus tutup.

Penelitian ini bertujuan untuk menguji pengaruh pembiayaan ultra mikro PT. Pegadaian Cabang Syariah Cabbang Palu terhadap perkembangan usaha mikro, kecil, dan menengah di masa pandemi covid-19 periode tahun 2020

\section{TINJAUAN PUSTAKA}

\subsection{Pembiayaan Ultra Mikro}

Pembiayaan atau financing adalah pendanaan yang diberikan oleh suatu pihak lain untuk mendukung investasi yang telah direncanakan, baik dilakukan sendiri maupun lembaga. ${ }^{11}$ Dengan kata lain pembiayaan adalah pendanaan yang dikeluarkan untuk mendukung investasi yang telah direncanakan. ${ }^{12} 13$

\footnotetext{
${ }^{10}$ Muhammad Syamsuddin, Dampak Pandemi Covid- 19 Terhadap UMKM di Indonesia, diakses meelalui https://www.nu.or.id/post/read/123247/dam pak-pandemi-covid-19-terhadap-umkm-diindonesia, Kamis, September 2020

11 Nurdin, N., Ningrum, R., Bachmid, S., \& Jalil, A. (2021). Pengaruh Manfaat, Kepercayaan dan Kemudahan Penggunaan Terhadap Minat Nasabah Menggunakan Mobile Banking di Bank Mega Syariah Cabang Palu Jurnal Ilmu Perbankan dan Keuangan Syariah, 3(1), 30-45.

12Veithzal Rivai dan Arviyan Arivin, Islamic Banking, Jakarta: PT. Bumi Aksara, 2010, 681.

${ }^{13}$ Malkan, M., Kurniawan, I., Nurdin, N., \& Noval, N. (2021). Pengaruh Pengetahuan Tentang Pasar Modal Syariah Terhadap Minat Investasi Saham di Pasar Modal Syariah Jurnal Ilmu Perbankan dan Keuangan Syariah, 3(1), 57-73.
} 
Dalam lembaga keuangan konvensional pembiayaan juga disebut kredit, kredit berasal dari bahasa latin "credere" yang artinya percaya. ${ }^{14}$ Kata percaya yang dimaksud adalah bahwa pihak yang memberi kredit memberikan kepercayaan kepada pihak yang menerima kredit bahwa kredit yang diberikan harus dikembalikan sesuai dengan perjanjian yang telah disepakati. ${ }^{15}$

\section{Dalam}

\section{Peraturan}

Menteri

Keuangan

(PMK)

Nomor Ultra Mikro (UMi), pemerintah mulai melaksanankan skema pembiayaan UMi. Kemudian agar pembiayaan ini menjadi lebih efektif, efisien dan lebih menjangkau pelaku usaha ultra mikro, pemerintah mengatur kembali pembiayaan ultra mikro melalui PMK No.95/PMK.05/2018. PMK No.95/PMK.05/2018 disebutkan bahwa pembiayaan Ultra Mikro adalah program fasilitas pembiayaan kepada usaha ultra mikro baik dalam bentuk kredit konvensional maupun pembiayaan berdasarkan prinsip syariah. ${ }^{16}$

Pembiayaan UMi menyasar usaha mikro yang berada di lapisan terbawah, yang belum bisa difasilitasi perbankan melalui program Kredit Usaha Rakyat (KUR), fasilitas pembiayaan maksimal

${ }^{14}$ Nurdin, N., Azizah, W. N., \& Rusli, R. (2020). Pengaruh Pengetahuan,Kemudahan dan Risiko Terhadap Minat Bertransaksi Menggunakan Finansial Technology (Fintech) Pada Mahasiswa Institut Agama Islam Negeri (IAIN) Palu Jurnal Ilmu Perbankan dan Keuangan Syariah, 2(2), 199-222.

${ }^{15}$ Kasmir, Bank dan Lembaga Keuangan Lainnya, Jakarta: Raja Grafindo Persada, 2005, 9293.

${ }^{16}$ Republik Indonesia, Peraturan Menteri Keuangan Nomor 95/PMK.05/2018, Tentang Pembiayaan Ultra Mikro Pasal 1.
Rp10 Juta per nasabah. Pembiayaan ini disalurkan melalui Lembaga Keuangan Bukan Bank (LKBB). Saat ini lembaga yang menyalurkan antara lain: PT. Pegadaian (Persero), PT. Bahana Artha Ventura, serta PT. Permodalan Nasional Madani (Persero).

Pembiayaan ini berbeda dengan pembiayaan KUR dari skema, sumber dana, plafon dan lainnya. Berikut perbedaan nya:

Tabel 1. Perbedaan KUR dan UMI

\begin{tabular}{|l|l|l|}
\hline \multicolumn{1}{|c|}{ KRITERIA } & \multicolumn{1}{|c|}{ KUR } & \multicolumn{1}{|c|}{ UMi } \\
\hline $\begin{array}{l}\text { Lembaga } \\
\text { Penyalur }\end{array}$ & $\begin{array}{l}\text { Perbankan dan } \\
\text { Lembaga Keuangan }\end{array}$ & $\begin{array}{l}\text { Lembaga Keuangan } \\
\text { Bukan Bank (LKBB) }\end{array}$ \\
\hline Plafon & $\begin{array}{l}\text { sd. Rp25 juta (Mikro) } \\
\text { s.d Rp500 juta (ritel) }\end{array}$ & Maksimal Rp10 juta \\
\hline Penerima & $\begin{array}{l}\text { Usaha Mikro dan } \\
\text { Kecil }\end{array}$ & $\begin{array}{l}\text { Pelaku Usaha Ultra } \\
\text { Mikro }\end{array}$ \\
\hline Tenor Pinjaman & $\begin{array}{l}\text { Jangka Panjang (>1 } \\
\text { tahun) }\end{array}$ & $\begin{array}{l}\text { Jangka Pendek (<52 } \\
\text { minggu) }\end{array}$ \\
\hline Angunan & $\begin{array}{l}\text { Usaha Kecil } \\
\text { diperlukan angunan } \\
\text { sebagaimana } \\
\text { ketentuan Perbankan }\end{array}$ & $\begin{array}{l}\text { Untuk Pembiayaan } \\
\text { kelompok tidak ada } \\
\text { agunan }\end{array}$ \\
\hline $\begin{array}{l}\text { Pendampingan } \\
\text { dan Pelatihan }\end{array}$ & Tidak Wajib & Wajib \\
\hline $\begin{array}{l}\text { Konsep } \\
\text { Dukungan } \\
\text { Pemerintah }\end{array}$ & Subsidi Bunga & $\begin{array}{l}\text { PIP } \\
\text { pinjaman ke LKBB } \\
\text { dengan bunga 2\%-4\% }\end{array}$ \\
\hline $\begin{array}{l}\text { Prosedur } \\
\text { lpPinjaman }\end{array}$ & $\begin{array}{l}\text { Mekanisme } \\
\text { Perbankan }\end{array}$ & Mekanisme LKBB \\
\hline
\end{tabular}

2.2

Usaha Mikro, Kecil dan
Menengah(UMKM)
UMKM) adalah unit usaha
produktif yang berdiri sendiri, yang dilakukan oleh orang perorangan atau badan usaha di semua sector ekonomi. 17 Usaha Mikro, Kecil, dan Menengah merupakan kegiatan usaha yang mampu memperluas lapangan kerja dan memberikan pelayanan ekonomi secara luas kepada masyarakat, dan dapat berperan dalam proses pemerataan dan peningkatan pendapatan masyarakat,

${ }^{17}$ Talil, A., \& Hamzah, S. A. (2020). Pengaruh Bagi Hasil dan Kebutuhan Modal Terhadap Minat UMKM Mengaiukan Pembiavaan Pada Lembaga Keuangan Svariah di Kota Palu. Turnal Ilmu Perbankan dan Keuangan Syariah, 2(2),186.. 
mendorong pertumbuhan ekonomi, dan berperan dalam mewujudkan stabilitas nasional. Menurut UU No.20 Tahun 2008 Pasal 1 disebutkan bahwa :18

1) Usaha Mikro adalah usaha produktif milik orang perorangan dan/atau badan usaha perorangan yang memiliki kekayaan bersih (tidak termasuk tanah dan bangunan) paling banyak Rp. 50.000.000,- (lima puluh juta rupiah) dan hasil penjualan tahunan (omzet/tahun) paling banyak Rp. 300.000.000,- (tiga ratus juta rupiah).

2) Usaha Kecil adalah usaha ekonomi produktif yang berdiri sendiri, yang dilakukan oleh orang perorangan atau badan usaha yang bukan merupakan anak perusahaan atau bukan cabang perusahaan yang dimiliki, dikuasai, atau menjadi bagian baik langsung maupun tidak langsung dari Usaha Menengah atau Usaha Besar. Kriteria dari usaha kecil adalah memiliki kekayaan bersih lebih dari Rp50.000.000,00 (lima puluh juta rupiah) sampai dengan paling banyak Rp500.000.000,00 (lima ratus juta rupiah) tidak termasuk tanah dan bangunan tempat usaha dan memiliki hasil penjualan tahunan lebih dari Rp300.000.000,00 (tiga ratus juta rupiah) sampai dengan paling banyak Rp2.500.000.000,00 (dua milyar lima ratus juta rupiah).

3) Usaha Menengah adalah usaha ekonomi produktif yang berdiri sendiri, yang dilakukan oleh orang perorangan atau badan usaha yang bukan merupakan anak perusahaan atau cabang perusahaan yang dimiliki, dikuasai, atau menjadi

${ }^{18}$ Republik Indonesia, Undang-undang Nomor 20 Tahun 2008, Tentang Usaha Mikro, Kecil dan Menengah Pasal 1. bagian baik langsung maupun tidak langsung dengan Usaha Kecil atau Usaha Besar. Kriteria memiliki kekayaan bersih lebih dari Rp500.000.000,00 (lima ratus juta rupiah) sampai dengan paling banyak Rp10.000.000.000,00 (sepuluh milyar rupiah) tidak termasuk tanah dan bangunan tempat usaha dan memiliki hasil penjualan tahunan lebih dari Rp2.500.000.000,00 (dua milyar lima ratus juta rupiah) sampai dengan paling banyak Rp50.000.000.000,00 (lima puluh milyar rupiah).

\subsection{Karakteristik Usaha Mikro, Kecil dan Menengah}

Karakteristik UMKM merupakan sifat atau kondisi faktual yang melekat pada aktifitas usaha maupun perilaku pengusaha yang bersangkutan dalam menjalankan bisnisnya. Karakteristik ini yang menjadi ciri pembeda antar pelaku usaha sesuai dengan skala usahanya. Berikut karakteristik UMKM, yaitu :19

1) Usaha Mikro. Beberapa kriteria usaha mikro di antaranya adalah Jumlah karyawan kurang dari 10 orang, Jenis barang komoditi tidak selalu tetap; sewaktu-waktu dapat berganti, Tempat usahanya tidak selalu menetap; sewaktu-waktu dapat pindah tempat, belum melakukan administrasi keuangan yang sederhana sekalipun, Tidak memisahkan keuangan keluarga dengan keuangan usaha, Sumber daya manusia (pengusaha) belum memiliki jiwa wirausaha yang memadai, Tingkat pendidikan ratarata relatif sangat rendah, Umumnya belum akses kepada perbankan, namun sebagian sudah akses ke

\footnotetext{
${ }^{19}$ Kerjasama Lembaga Pengembangan Perbankan Indonesia (LPPI) dan Bank Indonesia, Profil Bisnis UMKM, (Jakarta: 2015), 12.
} 
lembaga keuangan non bank, dan Umumnya tidak memiliki izin usaha atau persyaratan legalitas lainnya termasuk NPWP.

2) Usaha Kecil. Beberapa kriteria usaha kecil di antaranya adalah : Jumlah karyawan kurang dari 30 orang,Jenis barang/komoditi yang diusahakan umumnya sudah tetap tidak gampang berubah, Lokasi/tempat usaha umumnya sudah menetap tidak berpindah-pindah, Pada umumnya sudah melakukan administrasi keuangan walau masih sederhana, Keuangan perusahaan sudah mulai dipisahkan dengan keuangan keluarga, Sudah membuat neraca usaha, Sudah memiliki izin usaha dan persyaratan legalitas lainnya termasuk NPWP, Sumber daya manusia (pengusaha) memiliki pengalaman dalam berwirausaha, Sebagian sudah akses ke perbankan dalam keperluan modal, Sebagian besar belum dapat membuat manajemen usaha dengan baik seperti business planning atau rencana bisnis..

3) Usaha Menengah. Beberapa kriteria usama menengah adalah : Jumlah karyawan maksimal 300 orang, Memiliki manajemen dan organisasi yang lebih baik, dengan pembagian tugas yang jelas antara lain, bagian keuangan, bagian pemasaran dan bagian produksi, Telah melakukan manajemen keuangan dengan menerapkan sistem akuntansi dengan teratur sehingga memudahkan untuk auditing dan penilaian atau pemeriksaan termasuk oleh perbankan, Telah melakukan aturan atau pengelolaan dan organisasi perburuhan, Sudah memilki persyaratan legalitas antara lain izin tetangga, Sudah memiliki akses kepada sumber-sumber pendanaan perbankan. Adapun di antara contohnya adalah.

Usaha Mikro Kecil dan Menengah (UMKM) mempunyai peran penting dan strategis dalam pembangunan ekonomi nasional. Selain berperan dalam pertumbuhan ekonomi dan penyerapan tenaga kerja, UMKM juga berperan dalam mendistribusikan hasil-hasil pembangunan. Peran penting UMKM tidak hanya berarti bagi pertumbuhan di kota-kota besar tetapi berarti juga bagi pertumbuhan ekonomi di pedesaan. Berikut beberapa peran penting UMKM :20

1) UMKM berperan dalam memberikan pelayanan ekonomi secara luas kepada masyarakat, proses pemerataan dan peningkatan pendapatan masyarakat, proses pemerataan dan peningkatan pendapatan masyarakat, mendorong pertumbuhan ekonomi, serta mewujudkan stabilitas nasional.

2) UMKM juga sangat membantu negara/pemerintah dalam hal penciptaan lapangan kerja baru dan lewat UMKM juga banyak terciptanya unit-unit kerja baru yang menggunakan tenaga-tenaga baru yang mendukung pendapatan rumah tangga.

3) UMKM memiliki fleksibilitas yang tinggi jika dibandingkan dengan usaha yang berkapasitas lebih besar.

4) Tulang punggung perekonomian nasional karena merupakan populasi pelaku usaha dominan $(99,9 \%)$

5) Menyumbang volume ekspor mencapai 14,06\% (Rp166,63 Triliun)

6) Pembentukan Modal Tetap Bruto (PMTB) nasional sebesar 52,33\% (Rp830,9 Triliun)

${ }^{20}$ Ibid, 16-17. 


\subsection{Pandemi Covid-19}

Pandemi covid-19 merupakan kejadian/peristiwa tersebarnya penyakit koronavirus 2019 di seluruh Negara di dunia. Penyakit tersebut disebabkan oleh koronavirus jenis baru yang diberi nama SARS-CoV-2. Wabah covid -19 awalnya muncul di Wuhan, Hubei, Tiongkok pada tanggal 13 Desember 2019 dan ditetapkan sebagai pandemi oleh Organisasi Kesehatan Dunia pada tanggal 11 Maret 2020. Virus SAR tersebut dengan cepat menyebar di antara orang-orang, dimana penyebarannya terjadi baik secara langsung maupun tidak langsung, seperti melalui percikan pernapasan (droplet) yang dihasilkan selama batuk, dapat pula menyebar akibat bersin, pernapasan normal, menyentuh benda yang terkontaminasi lalu kemudian menyentuh wajah seseorang. ${ }^{21}$

Di Indonesia, pandemi covid-19 mulai diketahui pada tanggal 2 Maret 2020. Ketika itu ada 2 orang warga Indonesia yang teronfirmasi tertular dari salah seorang warga jepang. Pada tanggal 9 April 2020, Pandemi covid-19 sudah menyebar ke 4 propinsi. Di antara propinsi di Indonesia yang terpapar paling banyak adalah propinsi Jawa Timur, DKI Jakarta, dan Sulawesi Selatan. Untuk mencegah penyebarannya, maka pemerintah mengkampanyekan beberapa cara sederhana mulai dari menjaga jarak, sering mencuci tangan, menggunakan masker bahkan sampai kepada anjuran Pembatasan Sosial Berskala Besar serta mengharuskan warga/masyarakat untuk melakukan berbagai aktifitasnya dari rumah (stay at home). ${ }^{22}$

${ }^{21}$ Wikipedia, Pandemi Covid-19 diakses melalui https://id.wikipedia.org

22Rahmi Rosita, "Pengaruh Pandemi Covid-19 Terhadap UMKM, Jurnal Lentera

\section{METHODOLOGY}

Jenis penelitian ini adalah survey dengan pendekatan kuantitatif. ${ }^{23}$ Menggunakan jenis penelitian survey karena dalam pengumpulan data penulis menghimpun informasi dari para responden menggunakan kuisioner sebagai pengumpulan data yang pokok.

Populasi dalam penelitian ini adalah pelaku UMKM di kota Palu yang memperoleh pembiayaan ultra mikro di Pegadaian tahun 2020 sebanyak 30 UMKM. ${ }^{24}$ Mengingat jumlah populasi hanya 30 orang, maka sampel yang digunakan dalam penelitian ini adalah sampel jenuh, yakni teknik penentuan sampel bila semua anggota populasi digunakan sebagai sampel. Istilah lain sampel jenuh adalah sensus. ${ }^{25}$

Variabel dalam penelitian ini terdiri atas 2 variabel yakni pembiayaan Ultra Mikro (UMI sebagai variabel bebas (independent) dan perkembangan usaha

Bisnis-JRLAB, Vol. 2 Nomor 2 (November 2020), 109-110

${ }^{23}$ Marzuki, M., \& Nurdin, N. (2020). The Influence of Halal Product Expectation, Social Environment, and Fiqih Knowledge on Intention to Use Shariah Financial Technology Products. International Journal of Innovation, Creativity and Change, 13(1), 171-193.

${ }^{24}$ Iqbal, Staff Kantor Pegadaian Deputy Bisnis Area Palu, Wawancara oleh peneliti di Kantor Pegadaian Deputy Bisnis Area Palu, 15 Desember 2020. Data yang diberikan oleh pihak Pegadaian periode 2017 - 2020 adalah 100 orang. Akan tetapi dari 100 orang tersebut terdapat perubahan data, misalnya di tahun 2018 terkena dampak bencana sehingga penulis menemukan kesulitan untuk mendapatkan alamatnya, dan sebagian ada yang tidak bersedia untuk diwawancarai atau tidak merespon karena takut terkena virus Corona, sehingga peulis hanya dapat menjangkau sebanyak 30 pelaku UMKM.

${ }^{25}$ Sugiyono, Metode Penelitian, (Bandung: ALFABETA,2018), 85 
Mikro, Kecil dan Menengah sebagai variabel terikat (dependent). Teknik pengumpulan data yang digunakan dalam penelitian ini adalah wawancara, Wawancara digunakan untuk mengetahui jumlah UMKM yang menggunakan pembiayaan UMi di PT. Pegadaian pegadaian Syariah Cabang Palu.. Selain itu, juga digunakan kuisioner. Adapun isi kuisioner dalam penelitian ini terdiri atas tiga bagian, bagian pertama berisi tentang data diri responden atau keadaan umum responden., bagian kedua berisi tentang pembiayaan Ultra Mikro (UMi) yang diterima responden dan bagian ketiga berisi tentang perkembangan usaha responden sebelum dan sesudah menerima pembiayaan.Kuisioner dibagikan kepada pelaku UMKM dengan cara mendatangi langsung pelaku UMKM di rumahnya.

Untuk mengukur omzet penjualan dalam peneliian ini, digunakan Revenue (Sales) Growth Rate. Menurut Kesuma dalam Poernawarman Revenue (Sales) Growth Rate adalah kenaikan jumlah penjualan dari periode tahun ke tahun atau dari waktu ke waktu. ${ }^{26}$

Teknik analisis data pada penelitian ini menggunakan analisa kuantitatif, yaitu proses analisis terhadap data-data yang berbentuk angka dengan cara perhitungan secara statistik ${ }^{27}$. Adapun teknik analisis data

26Poermawarman, "Pengaruh Return On Asset, Sales Growth, Asset Growth, Cash Flow, Dan Likuiditas Terhadap Dividend Payout Ratio Perusahaan Perbankan Di Bursa Efek Indonesia Tahun 2009-2013", Jurnal Jom FEKON Vol. 2 No. (1 $\quad$ Februari 2015). https://media.neliti.com/media/publications/3 3870-ID-pengaruh-return-on-asset-sales-growthasset-growth-cash-flow-dan-likuiditas-terh.pdf (17 Februari 2021).

27Ermawati, dkk. "Pengaruh Penggunaan Media Sosial Terhadap Keputusan Pembelian Kuota kuantitatif yang digunakan terdiri atas uji asumsi klasik, uji autokorelasi, uji regresi linear sederhana, uji $t$ dan koefisien determinasi.

\section{HASIL DAN PEMBAHASAN}

\subsection{Deskripsi m Responden}

Pada pembahasan ini disajikan deskripsi data yang telah diperoleh dalam penelitian. Data hasil penelitian diperoleh secara langsung dari wawancara dan kuisioner, yaitu dengan mengajukan pertanyaan yang telah disiapkan oleh peneliti. Responden dalam penelitian ini berjumlah 30 pelaku UMKM PT. Pegadaian kota Palu yang men pembiayaan Ultra Mikro (UMi).

Besarnya persentase antara responden laki-laki dan perempuan disajikan pada diagram lingkaran berikut:

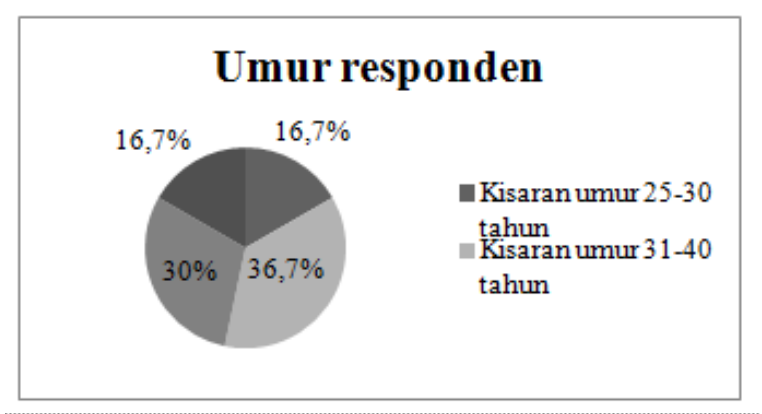

Berdasarkan gambar di atas, hasil identifikasi keadaan umum menurut jenis kelamin menunjukan 21 nasabah (70\%) adalah perempuan. Sedangkan laki-laki sebanyak 9 nasabah (30\%). Kesimpulannya mayoritas yang menjadi responden yaitu perempuan. Adapun

Internet Pada Mahasiswa Fakultas Ekonomi dan Bisnis Islam IAIN Palu," Jurnal Ilmu Ekonomi dan Bisnis Islam - JIEBI Vol.2 NO. 1 Tahun 2020, https://jurnaljiebi.org/index.php/jiebi/article/ view/22/17, 48, (24 Maret 2021). 
besarnya persentase berdasarkan kisaran umur responden disajikan dalam bentuk diagram lingkaran di bawah ini:

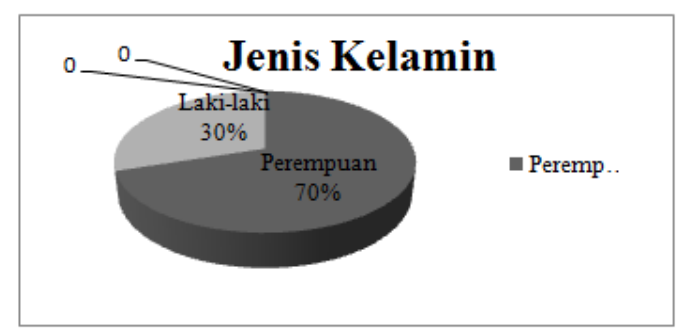

Berdasarkan gambar di atas, hasil identifikasi keadaan umum responden berdasarkan umur paling banyak dikisaran umur antara 31-40 tahun yaitu berjumlah 11 responden $(36,7 \%)$. Kisaran umur 41-50 berjumlah 9 responden (30\%) dan kisaran umur 25-30 tahun berjumlah 5 responden $(16,7 \%)$. Sedangkan untuk kisaran umur tertua yaitu 51-61 tahun berjumlah 5 responden $(16,7 \%)$. Untuk mengetahui besarnya persentase berdasarkan tingkat pendidikan disajikan pada diagram lingkaran di bawah ini:

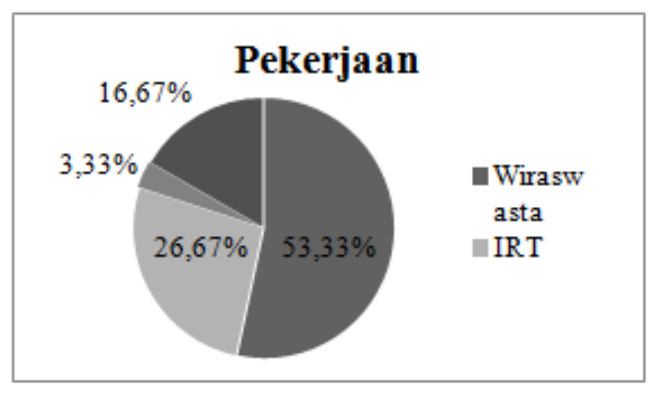

Berdasarkan gambar di atas, hasil identifikasi keadaan umum menurut tingkat pendidikan menunjukan 1 responden $(3,30 \%)$ lulusan $S D$, sebanyak 3 responden $(10 \%)$ lulusan SMP, lulusan SMA/SMK sebanyak 20 responden $(66,70 \%)$ dan lulusan S1 sebanyak 6 responden $(20 \%)$. Berdasarkan data di atas dapat disimpulkan bahwa mayoritas responden berlatar belakang pendidikan

SMA/SMK.

Untuk mengetahui besarnya persentase berdasarkan pekerjaan disajikan pada diagram lingkaran di bawah ini :

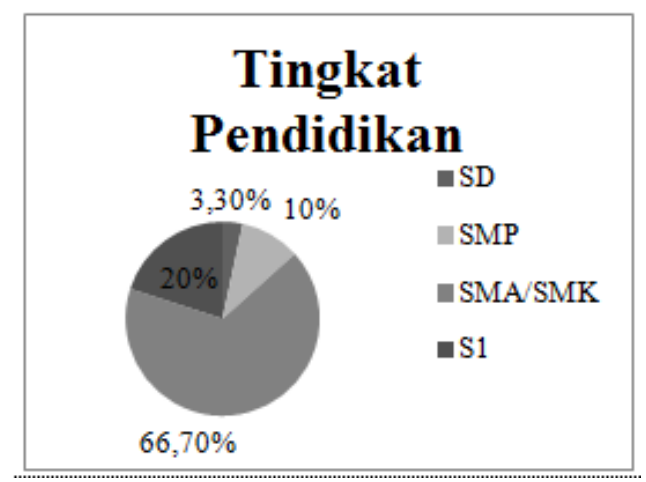

Berdasarkan gambar tersebut di atas, hasil identifikasi menunjukkan pekerjaan terbanyak responen adalah wiraswasta sebanyak 16 responden (5,3 $\%$ ), ibu rumah tangga (IRT) sebanyak 8 responden $(26,67 \%)$, honorer 1 responden (, \%) dan PNS/ASN sebanyak 5 responden $(16,67 \%)$. Adapun besarnya persentase responden berdasarkan jenis usaha disajikan dalam diagram batang sebagai berikut :

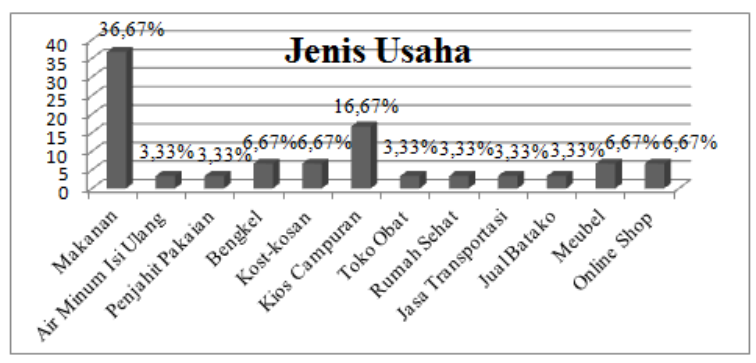

Berdasarkan gambar di atas, hasil identifikasi menunjukan jenis usaha terbanyak adalah penjual makanan sebesar 11 responden $(36,67 \%)$, kemudian usaha kios campuran sebesar 5 responden $(16,67 \%)$, usaha bengkel 2 responden $(6,67 \%)$, usaha kost-kosan 2 responden $(6,67 \%)$, usaha meubel 2 responden $(6,67 \%)$, usaha online shop 2 responden $(6,67 \%)$, usaha air minum isi ulang 1 responden $(3,33 \%)$, penjahit 
pakaian 1 responden (3,33\%), usaha toko obat 1 responden $(3,33 \%)$, usaha rumah sehat 1 responden $(3,33 \%)$, usaha jasa transportasi 1 responden $(3,33 \%)$ dan usaha jual batako 1 responden $(3,33 \%)$. Besarnya persentase berdasarkan lama usaha responden disajikan dalam bentuk diagram lingkaran di bawah ini:

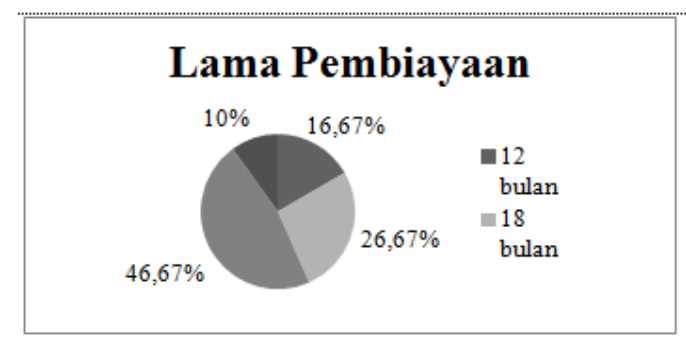

Berdasarkan gambar di atas, hasil identifikasi menunjukan keadaan umum responden berdasarkan lama usaha paling lama yaitu sekitar $11-17$ tahun berjumlah 3 responden (10\%). Lalu kisaran 6 - 10 tahun berjumlah 9 responden $(30 \%)$ dan 1- 5 tahun berjumlah 18 responden (60\%).

\subsection{Pembiayaan Ultra Mikro (UMi)} Yang Diterima Responen Informasi yang disajikan selanjutnya adalah besar jumlah pembiayaan UMi yang diterima oleh responden serta lamanya pembiayaan. . Adapun besarnya persentase jumlah pembiayaan yang digunakan dapat dilihat pada diagram batang berikut :

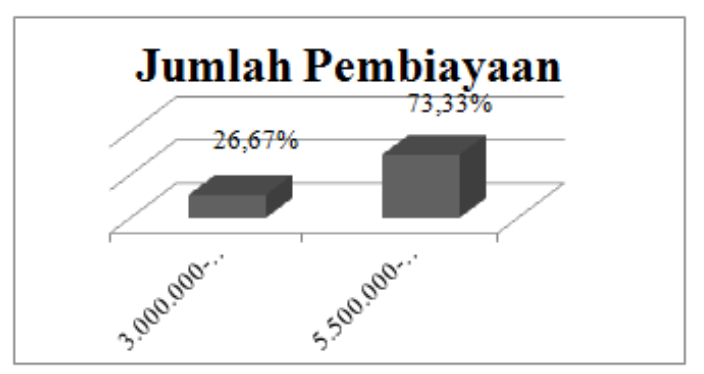

Berdasarkan diagram batang di atas, diketahui bahwa pembiayaan UMi yang paling besar diberikan kepada responden adalah Rp.10.000.000.
Sedangkan jumlah pembiayaan yang paling banyak diterima oleh responden di kisaran Rp. 5.500.000-Rp.10.000.000 berjumlah 22 responden $(73,33 \%)$ dan pembiayaan kisaran Rp.3.000.000Rp.5.000.000 berjumlah 8 responden (26,67\%). Untuk mengetahui Besarnya persentase lama pembiayaan yang digunakan dapat dilihat pada diagram lingkaran berikut:

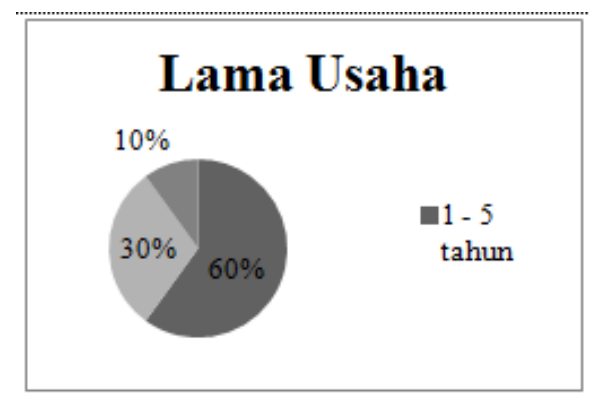

Berdasarkan diagram lingkaran di atas, diketahui bahwa jangka waktu pembiayaan terbanyak yang dipilih oleh responden adalah 24 bulan sebanyak 14 responden $(46,67 \%)$, lalu 18 bulan sebanyak 8 responden $(26,67 \%), 12$ bulan sebanyak 5 responden $(16,67 \%)$ dan 36 bulan sebanyak 3 responden (10\%). Dari data pendukung yang diperoleh responden tertarik menggunakan pembiayaan ini karena jangka waktu yang ditawarkan relatif lama dan bunga yang diambil juga tidak terlalu besar.

\subsection{Analisis Data Kuantitatif.}

\subsubsection{Uji Asumsi Klasik}

a. Uji Normalitas Data

Uji normalitas adalah pengujian data untuk melihat apakah nilai residual terdistribusi normal atau tidak. Untuk mengetahui apakah data dalam penelitian ini terdistribusi normal atau tidak maka dilakukan pengujian dengan pendekatan Kolmogorov-Smirnov. Berikut adalah hasil pengujiannya: 
Tabel 2.Normalitas

One-Sample Kolmogorov-Smirnov Test

\begin{tabular}{|c|c|c|}
\hline & & $\begin{array}{c}\text { Unstandardized } \\
\text { Residual } \\
\end{array}$ \\
\hline \multicolumn{2}{|l|}{$\mathrm{N}$} & \\
\hline \multicolumn{2}{|c|}{$\begin{array}{l}\text { Normal Parameters }{ }^{\mathrm{a}, \mathrm{b}} \\
\text { Mean }\end{array}$} & , 59000000 \\
\hline $\begin{array}{l}\text { Most Extreme } \\
\text { Differences }\end{array}$ & $\begin{array}{l}\text { Absolute } \\
\text { Positive } \\
\text { Negative }\end{array}$ & $\begin{array}{r}, 116 \\
, 097 \\
-, 116 \\
, 116\end{array}$ \\
\hline \multicolumn{2}{|c|}{$\begin{array}{l}\text { Test Statistic } \\
\text { Asymp. Sig. (2-tailed) }\end{array}$} & $200^{\circ}$ \\
\hline
\end{tabular}

a. Test distribution is Normal.

b. Calculated from data.

c. Lilliefors Significance Correction.

$\mathrm{d}$. This is a lower bound of the true significance.

Dari tabel One-Sample KolmogorovSmirnov Test diperoleh angka probabilitas atau Asym. Sig. (2-tailed) sebesar 0,200, nilai ini dibandingkan dengan 0,05 bernilai lebih besar maka data dalam penelitian ini adalah normal.

\section{b. Uji Heteroskedastisitas}

Uji asumsi ini bertujuan untuk mengetahui apakah dalam sebuah model regresi terjadi ketidaksamaan varian dari residual antara pengamatan satu dan pengamatan yang lain. Heteroskedastisitas diuji dengan menggunakan uji koefisien korelasi Rank Spearman yaitu mengkorelasikan antara absolut residual hasil regresi dengan semua variabel bebas. Untuk mendeteksi ada tidaknya heteroskedastisitas dilihat dari nilai probabilitas setiap variabel independen. Jika probabilitas > 0,05 berarti tidak terjadi heteroskedastisitas dan sebaliknya jika probibalitas $<0,05$ berarti terjadi heteroskedastisitas. Hasil uji heteroskedastisitas ditunjukan pada tabel berikut:
Tabel 3

Heteroskedastisitas

Correlations

\begin{tabular}{|c|c|c|c|c|}
\hline & & & ABS RES1 & $\begin{array}{l}\text { Pembiayaan } \\
\text { Ultra Mikro }\end{array}$ \\
\hline \multirow[t]{2}{*}{$\begin{array}{l}\text { Spearman's } \\
\text { rho }\end{array}$} & ABS_RES1 & $\begin{array}{l}\text { Correlation } \\
\text { Coefficient } \\
\text { Sig. (2-tailed) } \\
\text { N }\end{array}$ & 1,000 & $\begin{array}{r}-, 105 \\
, 582 \\
30\end{array}$ \\
\hline & $\begin{array}{l}\text { Pembiayaan } \\
\text { Ultra Mikro }\end{array}$ & $\begin{array}{l}\text { Correlation } \\
\text { Coefficient } \\
\text { Sig. (2-tailed) } \\
\text { N }\end{array}$ & $\begin{array}{r}-, 105 \\
, 582 \\
30\end{array}$ & $\begin{array}{r}1,000 \\
30\end{array}$ \\
\hline
\end{tabular}

Dari hasil tabel di atas menunjukan bahwa variabel yang diuji Pembiayaan Ultra Mikro tidak mengandung heteroskedastisitas karena signifikansi hasil korelasi lebih besar dari 0,05 (5\%), sehingga bila data diperbesar tidak menyebabkan kesalahan semakin besar pula.

\subsubsection{Uji Autokorelasi}

Uji asumsi ini bertujuan untuk menguji dalam satu model regresi linear ada korelasi antara kesalahan pengganggu pada periode $t$ dengan kesalahan pada periode $\mathrm{t}-1$ (sebelumnya). Jika ada korelasi, maka dinamakan ada problem autokorelasi. Pada penelitian ini menggunakan autokorelasi Run Test. Run Test digunakan untuk melihat apakah data residual terjadi secara random atau tidak (sistematis). Apabila nilai signifikansi lebih kecil dari 0,05 maka terdapat gejala autokorelasi sebalikna jika lebih besar dari 0,05 maka tidak terdapat gejala autokorelasi. Hasil uji autokorelasi ditunjukan pada tabel berikut: 
Tabel 4.

Uji Autokorelasi

Run Test

\begin{tabular}{|l|r|}
\hline & \multicolumn{2}{|c|}{$\begin{array}{c}\text { Unstandardized } \\
\text { Residual }\end{array}$} \\
\hline Test Value &, 03629 \\
Cases $<$ Test Value & 15 \\
Cases $>=$ Test Value & 15 \\
Total Cases & 30 \\
Number of Runs & 18 \\
$Z$ &, 557 \\
Asymp. Sig. (2-tailed) &, 577 \\
\hline a. Median & \\
\hline
\end{tabular}

Dari tabel di atas dapat disimpulkan bahwa nilai Asymp. Sig. (2tailed) lebih besar dari 0,05 hal ini berarti data yang dipergunakan tersebar (random). Dapat diketahui bahwa tidak terdapat masalah autokorelasi variabel independen, sehingga model regresi layak digunakan.

\subsubsection{Analisis Regresi Linear Sederhana}

Analisis regresi sederhana adalah hubungan secara linear antara satu variabel independen $(X)$ dan variabel dependen (Y). Analisis ini untuk mengetahui arah hubungan antara variabel.

Tabel 5.

Uji Nilai Signifikan

ANOVA $^{a}$

\begin{tabular}{|c|c|c|c|c|c|}
\hline Model & $\begin{array}{l}\text { Sum of } \\
\text { Squares }\end{array}$ & Df & $\begin{array}{c}\text { Mean } \\
\text { Square }\end{array}$ & $\mathrm{F}$ & Sig. \\
\hline $\begin{array}{ll}1 & \text { Regression } \\
\text { Residual } \\
\text { Total }\end{array}$ & $\begin{array}{r}0,040 \\
10,148 \\
10,188\end{array}$ & $\begin{array}{r}1 \\
28 \\
29\end{array}$ & $\begin{array}{r}, 040 \\
, 362 \\
, 362\end{array}$ &, 110 &, $743^{6}$ \\
\hline
\end{tabular}

Tabel uji signifikasi di atas, digunakan untuk menentukan taraf signifikasi atau linieritas dari regresi. Kriteria dapat ditentukan berdasarkan uji nilai (Sig), dengan ketentuan jika nilai Sig $<0,05$. Berdasarkan data tabel di atas, diperoleh nilai Sig 0,743, berarti Sig. $>$ dari kriteria signifikan $(0,05)$. Dengan demikian model persamaan regresi berdasarkan data penelitian adalah tidak signifikan, atau model persamaan regresi tidak memenuhi kriteria.

\subsection{Uji Signifikansi (Uji t)}

Uji Parsial (t) Uji $t$ digunakan untuk mengetahui ada atau tidaknya pengaruh masing-masing variabel independent secara parsial terhadap variabel dependent yang diuji pada tingkat signifikan 0,05. Pengambilan keputusan dilakukan dengan kriteria:

a. Bila $t$ hitung $>$ dari $t$ tabel maka variabel independen berpengaruh terhadap variabel dependen

b. Jika nilai $\mathrm{t}$ hitung $<\mathrm{t}$ tabel, maka variabel independen tidak berpengaruh terhadap variabel dependen.

Hasil data uji signifikansi di tunjukan pada tabel berikut:

Tabel 6.

Uji Signifikansi

Coefficients $^{\mathbf{a}}$

\begin{tabular}{|c|c|c|c|c|c|}
\hline \multirow[b]{2}{*}{ Model } & \multicolumn{2}{|c|}{$\begin{array}{l}\text { Unstandardized } \\
\text { Coefficients }\end{array}$} & \multirow{2}{*}{\begin{tabular}{|c|}
$\begin{array}{c}\text { Standardized } \\
\text { Coefficients }\end{array}$ \\
Beta \\
\end{tabular}} & \multirow{2}{*}{$\mathrm{t}$} & \\
\hline & $\begin{array}{ll}\mathrm{B} \\
\end{array}$ & \begin{tabular}{|l|} 
Std. Error \\
\end{tabular} & & & \\
\hline $\begin{array}{l}\text { (Constant) } \\
\text { Pembiayaan } \\
\text { Ultra Mikro }\end{array}$ & $\begin{array}{r}, 407 \\
-1,446 \mathrm{E}-8\end{array}$ & $\begin{array}{l}, 296 \\
, 000\end{array}$ &,- 062 & \begin{tabular}{|l|}
1,376 \\
,- 331
\end{tabular} &, 180 \\
\hline
\end{tabular}

Dari tabel di atas dihasilkan bahwa koefisien $t_{\text {hitung }}-0,331<t_{\text {tabel }} 12,706$ sehingga variabel independen tidak berpengaruh terhadap variabel dependen dan signifikansi bernilai 0,743 $>0,05$. Maka dapat disimpulkan bahwa variabel independen tidak memiliki pengaruh yang signifikan terhadap variabel dependen atau hipotesis $\mathrm{H} 1$ yang berbunyi "Pembiayaan Ultra Mikro (UMi) berpengaruh signifikan terhadap Perkembangan Usaha Mikro, Kecil dan Menengah (UMKM)" ditolak.

\subsection{Koefisien Determinasi (R Square)}

Koefisien determinasi $\left(\mathrm{R}^{2}\right)$ 
bertujuan untuk mengetahui seberapa besar kemampuan variabel independen menjelaskan variabel dependen. Dalam output SPSS, koefisien determinasi terletak pada tabel Model Summary b dan tertulis $R$ Square. Hasil uji koefisien determinasi (R Square) ditunjukan pada tabel berikut:

Tabel 7.

Determinasi Koefisien (R Square) Model Summary

\begin{tabular}{|l|c|r|r|r|}
\hline Model & R & R Square & $\begin{array}{c}\text { Adjusted R } \\
\text { Square }\end{array}$ & $\begin{array}{l}\text { Std. Error of } \\
\text { the Estimate }\end{array}$ \\
\hline 1 &, $062^{\mathrm{a}}$ &, 004 &,- 032 &, 60203 \\
\hline
\end{tabular}

a. Predictors: (Constant), Pembiayaan Ultra Mikro

Melalui tabel di atas dipeoleh nilai $\mathrm{R}$ Square sebesar 0,004 atau $0,04 \%$.. Sehingga dapat disimpulkan bahwa variabel $X$ tidak terdapat pengaruh yang signifikan terhadap variabel $\mathrm{Y}$. Dari hasil pengujian hipotesis terbukti bahwa "Tidak Terdapat Pengaruh yang Signifikan antara Pembiayaan Ultra Mikro (UMi) terhadap Perkembangan UMKM PT. Pegadaian Kota Palu" karena pengaruh pembiayaan UMi sangat rendah terhadap perkembangan UMKM yaitu sebesar $0,04 \%$ sedangkan 99,96\% perkembangan UMKM dipengaruhi oleh variabel lain yang tidak diteliti, $t_{\text {hitung }}<\mathrm{t}_{\text {tabel }}$ sehingga H1 ditolak.

\subsection{Pembahasan Hasil Penelitian.}

Penelitian ini bertujuan untuk menguji apakah pembiayaan $\mathrm{UMi}$ berpengaruh signifikan terhadap perkembangan UMKM dan untuk menguji pengaruh pembiayaan UMi terhadap perkembangan UMKM sebelum dan sesudah mendapatkan pembiayaan PT. Pegadaian Kota Palu.

\subsubsection{Pengaruh Pembiayaan Ultra Mikro (UMi) Terhadap Perkembangan UMKM}

Pada uji regresi sederhana ketika hasil konstanta bernilai positif maka tidak terjadi masalah dan bisa diabaikan selama model regresi yang diuji sudah memenuhi uji asumsi klasik. Karena uji regresi linear sederhana digunakan untuk memprediksi Y berdasarkan nilai perubahan X.28 Maka yang menjadi perhatian adalah $X$ nya bukan nilai konstanta. Berdasarkan hasil perhitungan koefisien regresi sederhana memperlihatkan nilai konstanta adalah positif sebesar 0,407 . Koefisien variabel $X$ adalah sebesar -1,446, sehingga diperoleh persamaan $\mathrm{Y}=0,407+$ 1,446X. Secara sistematis, nilai konstanta ini menyatakan bahwa pada pembiayaan UMi 0 , maka perkembangan UMKM memiliki nilai 0,407 .

Selanjutnya nilai negatif $(-1,446)$ yang terdapat pada koefisien regresi variabel bebas (Pembiayaan UMi) menggambarkan bahwa arah hubungan antara variabel bebas (Pembiayaan UMi) dengan variabel terikat (Perkembangan UMKM) adalah tidak searah, dimana setiap kenaikan satu satuan variabel pembiayaan UMi akan menyebabkan kenaikan perkembangan UMKM -1,446 dan pada hasil penelitian ini menunjukkan bahwa pembiayaan UMi memiliki pengaruh negatif dan tidak signifikan terhadap perkembangan UMKM dengan hasil koefisien $t_{\text {hitung }}-0,331<t_{\text {tabel }} 12,706$ sehingga variabel independen tidak berpengaruh terhadap variabel dependen dan signifikansi bernilai 0,743

\footnotetext{
${ }^{28}$ Eka Aprilia, "Pengaruh Produk Pembiayaan Mikro 75 iB Terhadap Perkembangan Usaha Kecil dan Menengah (UMKM) Pada Bank Syariah Kantor Cabang Tanjung Karang Periode 2010-2015", (skripsi: Universitas Islam Negeri Raden Intan Lampung, 2017).
} 
$>0,05$. Maka dapat disimpulkan bahwa variabel independen tidak memiliki pengaruh yang signifikan terhadap variabel dependen atau hipotesis $\mathrm{H} 1$ yang berbunyi "Pembiayaan Ultra Mikro (UMi) berpengaruh signifikan terhadap Perkembangan Usaha Mikro, Kecil dan Menengah (UMKM)" ditolak.

Berdasarkan hasil penelitian ditemukan bahwa besarnya jumlah pemberian pembiayaan tidak berpengaruh positif terhadap perkembangan UMKM dalam aspek omzet penjualan. Hal ini disebabkan oleh beberapa faktor, yaitu:

a. Karena pembiayaan yang dilakukan oleh pelaku UMKM terjadi pada masa pandemi Covid-19 yang menyebabkan konsumen berkurang sehingga usahanya mengalami penurunan pendapatan penjualan yang drastis bahkan beberapa pelaku UMKM harus menutup usahanya karena lesunya ekonomi dan minat beli masyarakat.

b. Jumlah pembiayaan yang diberikan terbatas yaitu hanya sampai Rp.10.000.000 saja.

c. Beberapa pelaku UMKM yang mendapatkan pembiayaan tidak menggunakan uang pembiayaan tersebut untuk keperluan pengembangan usahanya, melainkan untuk keperluan pribadi.

Perbandingan pada penelitian terdahulu dan sekarang adalah hasil penelitian yang dilakukan oleh Eka Aprilia, dengan judul "Pengaruh Produk Pembiayaan Mikro 75 iB Terhadap Perkembangan Usaha Kecil dan Menengah (UMKM) Pada Bank Syariah Kantor Cabang Tanjung Karang Periode 2010-2015". ${ }^{29}$ Menunjukkan

\begin{tabular}{rlrr}
\hline${ }^{29} \mathrm{Eka}$ & Aprilia, & “Pengaruh & Produk \\
Pembiayaan & Mikro & $75 \mathrm{iB}$ & Terhadap
\end{tabular}

hasil bahwa pembiayaan mikro 75 iB memiliki pengaruh positif dan signifikan terhadap perkembangan UMKM dengan hasil uji T-hitung sebesar 7.656> T-tabel 2.010 sehingga variabel independen berpengaruh terhadap variabel dependen dan signifikan bernilai $0.00<0.05$ sehingga Ho ditolak dan Ha diterima.

Penelitian yang dilakukan oleh Isniani Nurrohmah, dengan judul "Analisis Perkembangan Usaha Mikro Kecil dan Menengah Sebelum dan Sesudah Menerima Pembiayaan Musyarakah Pada Koperasi Jasa Keuangan Syariah BMT (Studi Kasus: BMT Beringharjo Yogyakarta)". ${ }^{30}$ Menunjukkan hasil bahwa ada perbedaan antara omset penjualan sebelum dan sesudah pembiayaan. Ada kenaikan pada omset penjualan sesudah pembiayaan yaitu sebesar $83,57 \%$, ada perbedaan antara jumlah tenaga kerja sebelum dan sesudah pembiayaan. Ada kenaikan pada jumlah tenaga kerja sesudah pembiayaan yaitu sebesar $77,42 \%$, jumlah pelanggan sesudah lebih banyak dibanding dengan jumlah pelanggan sebelum, ada kenaikan pelanggan sesudah pembiayaan sebesar $55,97 \%$.

Penelitian yang dilakukan oleh Maya Sari, dengan judul "Pengaruh Pembiayaan Mudharabah Terhadap

Perkembangan Usaha Kecil dan Menengah (UMKM) Pada Bank Syariah Kantor Cabang Tanjung Karang Periode 2010-2015", (skripsi: Universitas Islam Negeri Raden Intan Lampung, 2017).

${ }^{30}$ Isniani Nurrohmah, "Analisis Perkembangan Usaha Mikro, Kecil dan Menengah Sebelum dan Sesudah Menerima Pembiayaan Musyarakah pada Koperasi Jasa Keuangan Syariah BMT (Studi Kasus: BMT Beringharjo Yogyakarta)", (Skripsi Program Sarjana Pendidikan Ekonomi Fakultas Ekonomi Universitas Negeri Yogyakarta, 2015).

e-ISSN: 2686-6625 
Perkembangan Usaha Mikro, Kecil dan Menengah (UMKM) BMT Sepakat Tanjung Karat Barat". ${ }^{31}$ Hasil penelitian ini menunjukan bahwa pembiayaan murabahah secara parsial berpengaruh positif dan signifikan terhadap perkembangan UMKM. Dapat dilihat dari uji $t$ pembiayaan murabahah yaitu t-hitung $>$ t-tabel sebesar $6.212>$ T-tabel 2.005 sehingga variabel independen berpengaruh terhadap variabel dependen dan signifikansi bernilai 0.00 $<0.05$.

\section{Perkembangan UMKM}

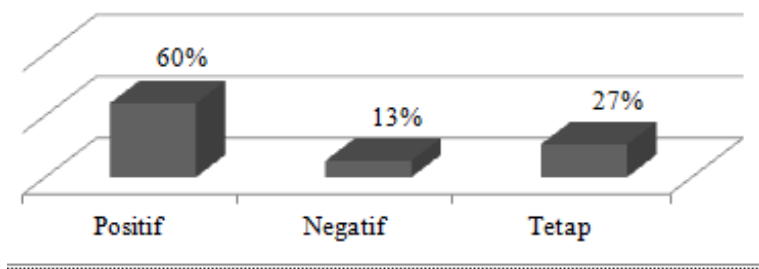

\subsubsection{Perkembangan UMKM Sebelum} dan Sesudah Mendapatkan Pembiayan Ultra Mikro (UMi)

Perkembangan usaha UMKM sebelum dan sesudah menerima pembiayaan UMi pada PT. Pegadaian Kota Palu dapat dilihat dari omzet penjualannya yang merupakan indikator perkembangan UMKM dalamm penelitian ini. Omzet penjualan ini berupa rata-rata total penjualan yang diperoleh responden atau pelaku UMKM dalam sebulan.

Untuk melihat apakah terjadi peningkatan omzet penjualan sebelum dan sesudah mendapatkan pembiayaan UMi, peneliti menggunakan perhitungan rasio Revenue (Sales) Growth

${ }^{31}$ Maya Sari, "Pengaruh Pembiayaan Mudharabah Terhadap Perkembangan Usaha Mikro, Kecil dan Menengah (UMKM) BMT Sepakat Tanjung Karat Barat", (Skripsi: Universitas Islam Negeri Intan Lampung, 2019).
Rate. Revenue (Sales) Growth Rate adalah kenaikan jumlah penjualan dari periode tahun ke tahun atau dari waktu ke waktu. Perhitungan tingkat penjualan UMKM dibandingkan pada akhir periode dengan penjualan yang dijadikan periode dasar. Apabila nilai perbandingan semakin besar, maka dapat dikatakan bahwa tingkat pertumbuhan penjualan semakin baik atau positif sebaliknya bila menurun berati tingkat pertumbuhan penjualan negatif.

Berikut data perkembangan UMKM berdasarkan omzet penjualan sebelum dan sesudah pembiayaan yang diperoleh oleh peneliti dari 30 responden pelaku UMKM yang menggunakan pembiayaan UMi PT. Pegadaian Kota Palu yang disajikan dalam bentuk diagram batang di bawah ini:

\section{Perkembangan UMKM}

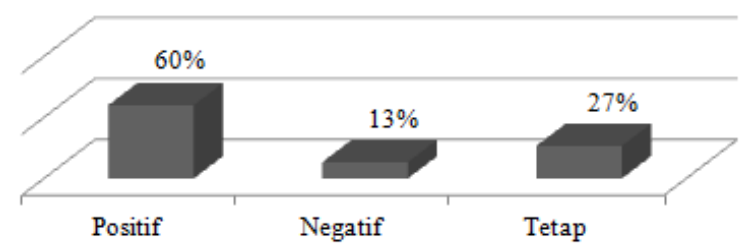

Berdasarkan hasil data yang telah diuraikan pada diagram di atas diperoleh hasil bahwa dari 30 responden terdapat 18 responden yang mengalami pertumbuhan penjualan positif $(60 \%)$. Sedangkan 4 responden mengalami penurunan penjualan atau negatif $13 \%$ dan 8 responden tidak mengalami pertumbuhan penjualan atau tetap $(27 \%)$.

Berdasarkan tabel tersebut, maka dapat disimpulkan bahwa rata-rata pelaku UMKM yang menggunakan pembiayaan UMi di PT. Pegadaian mengalami peningkatan omzet 
penjualan sesudah mendapatkan penjualan yaitu sebanyak 18 responden (60\%) dengan pertumbuhan usaha berkisar antara $24 \%-204 \%$.

\subsubsection{Pandangan Ekonomi Islam Terhadap Sewa Modal (Bunga) pada Pembiayaan Ultra Mikro (UMi)}

Dalam sistem pembiayaan konvensional, akad yang berlaku antara perusahaan pembiayaan dan konsumen berbasis bunga, dimana perusahaan pembiayaan bertindak sebagai kreditur dan konsumen berperan sebagai debitur. ${ }^{32}$ Dalam penelitian ini PT. Pegadaian bertindak sebagai kreditur dan Pelaku UMKM sebagai debitur.

Sewa modal dalam pegadaian adalah sejumlah tambahan yang didasarkan pada pokok hutang yang sudah ditetapkan oleh pegadaian pada awal transaksi dalam bentuk persentase, yang harus dibayar nasabah pada saat melakukan pengangsuran saat jatuh tempo sebagai imbalan atas lama jangka waktu. Berikut jumlah besaran sewa modal yang telah ditetapkan untuk pembiayaan ultra mikro yang dihitung berdasarkan jangka waktu pembiayaan.

Penggunaan bunga sewa modal atau bunga yang digunakan dalam pembiayaan UMi di pegadaian jelas tidak sesuai dengan prinsip-prinsip syariah. Islam sangat jelas melarang penggunaan bunga karena termasuk dalam riba, merupakan perkara yang diharamkan dan dilarang oleh Alla swt. Sesuai firman Allah swt dalam Al-quran surah Al-Baqarah ayat 275 yang

\footnotetext{
${ }^{32}$ Ningsi, N. I. dan Hasan, H. Tiniauan Hukum Islam Terhadap Bunga Dalam Pembiavaan Konvensional dan Margin Dalam Pembiavaan, Iatishaduna: Iurnal Ilmiah Mahasiswa Hukum Ekonomi Suari'ah, Vol. 2, (2020), 35. http:/ /103.55.216.56/index.php/iqtishaduna/ar ticle/view/15137, 03 Maret 2021.
}

terjemahannya sebagai berikut:

“Orang-orang yang makan
(mengambil) riba tidak
$\begin{aligned} & \text { dapat } \\ & \text { berdiri melainkan }\end{aligned}$ seperti
kemasukan syaitan lantaran
(tekanan) penyakit gila. Keadaan
mereka yang demikian itu, adalah
disebabkan mereka berkata
(berpendapat), sesungguhnya jual
beli itu sama dengan riba,
padahal Allah r telah
menghalalkan jual beli dan
mengharamkan riba. ${ }^{33}$

Ayat di atas bermakna bahwa orang-orang yang memakan riba yakni melakukan transaksi riba dengan mengambil atau menerima kelebihan di atas modal dari orang yang butuh dengan mengeksploitasi atau memanfaatkan kebutuhannya, tidak dapat berdiri, yakni melakukan aktivitas, melainkan seperti berdirinya orang yang kemasukan setan karena gila. Mereka hidup dalam kegelisahan; tidak tenteram jiwanya, selalu bingung, dan berada dalam ketidakpastian, sebab pikiran dan hati mereka selalu tertuju pada materi dan penambahannya. Itu yang akan mereka alami di dunia, sedangkan di akhirat mereka akan dibangkitkan dari kubur dalam keadaan sempoyongan, tidak tahu arah yang akan mereka tuju dan akan mendapat azab yang pedih. ${ }^{34}$ Yang demikian itu

KEMENAG

${ }^{33}$ Republik Indonesia, Qur'an

https:/ / quran.kemenag.go.id/sura/2, Februari 2021).

34 Rusli, R., \& Nurdin, N. (2021). Understanding Indonesia millennia Ulama online knowledge acquisition and use in daily fatwa making habits. Education and Information Technologies. https://doi.org/10.1007/s10639021-10779-7 
karena mereka berkata dengan bodohnya bahwa jual beli sama dengan riba dengan logika bahwa keduanya sama-sama menghasilkan keuntungan. Mereka beranggapan seperti itu, padahal Allah telah menghalalkan jual beli dan mengharamkan riba.

Substansi keduanya berbeda, sebab jual beli menguntungkan kedua belah pihak (pembeli dan penjual), sedangkan riba sangat merugikan salah satu pihak. Barang siapa mendapat peringatan dari Tuhannya, setelah sebelumnya dia melakukan transaksi riba, lalu dia berhenti dan tidak melakukannya lagi, maka apa yang telah diperolehnya dahulu sebelum datang larangan menjadi miliknya yakni riba yang sudah diambil atau diterima sebelum turun ayat ini, boleh tidak dikembalikan, dan urusannya kembali kepada Allah. Barang siapa mengulangi transaksi riba setelah peringatan itu datang maka mereka itu penghuni neraka. Mereka kekal di dalamnya untuk selama-lamanya. ${ }^{35}$

Penggunaan bunga uang atas pinjaman (qard) yang digunakan di pegadaian adalah riba dan diharamkan Allah swt dalam al-quran. Riba adalah penetapan bunga atau melebihkan jumlah pinjaman saat pengembalian berdasarkan persentase tertentu dari jumlah pinjaman pokok yang dibebani kepada peminjam ${ }^{36}$ Sedangkan dalam sistem bunga sewa modal tambahan

\footnotetext{
${ }^{35}$ Badan Litbang dan Diklat Kementerian Agama Republik Indonesia, "Tafsir Ringkas AlQur'an AL-Karim (Tafsir Wajiz Jilid I, Bagian 1, 2016), Lajnah Pentashihan Mushaf Al-Quran, https://pustakalajnah.kemenag.go.id/detail/12 7, 129-130. (21 Maret 2021).

36Riba, Wikipedia Eksiklopedia Bebas, https://id.wikipedia.org/wiki/Riba, 12 April 2021.
}

sudah langsung dikenakan sejak terjadi transaksi ${ }^{37}$ artinya besarnya pembayaran bunga tetap seperti yang disepakati di awal akad, tanpa pertimbangan apakah usaha yang dijalankan oleh kreditur nantinya untung atau rugi.

Padahal berdasarkan data hasil wawancara yang diperoleh peneliti banyak pelaku UMKM yang mengalami kerugian atau penurunan pendapatan dikarenakan pandemi Covid-19 bahkan beberapa diantara nya harus menutup usahanya, karena lesunya ekonomi dan minat beli masyarakat. Hal ini tentu saja memberatkan bagi pelaku UMKM yang mengalami penurunan pendapatan dalam mengangsur pembiayaan nya.

\section{KESIMPULAN DAN SARAN}

Dari hasil pengolahan data dan analisis data dalam penelitian yang membahas tentang "Pengaruh Pembiayaan Ultra Mikro (UMi) Terhadap Perkembangan Usaha Mikro, Kecil dan Menengah (UMKM) PT. Pegadaian Kota Palu", dapat disimpulkan bahwa variabel pembiayaan tidak berpengaruh signifikan terhadap perkembangan UMKM yang dibuktikan dengan dengan hasil koefisien $t_{\text {hitung }}-0,331<t_{\text {tabel }} 12,706$ sehingga variabel independen tidak berpengaruh terhadap variabel dependen dan signifikansi bernilai 0,743 $>0,05$. Maka dapat disimpulkan bahwa variabel independen tidak memiliki pengaruh yang signifikan terhadap variabel dependen atau hipotesis $\mathrm{H} 1$ yang berbunyi "Pembiayaan Ultra Mikro (UMi) berpengaruh signifikan terhadap Perkembangan Usaha Mikro,

${ }^{37}$ Fatwa Majelis Ulama Indonesia, MUI Nomor 1 Tahun 2004, Tentang Bunga (Interest/Fai'dah), 433. 
Kecil dan Menengah (UMKM)" ditolak. Hasil penelitian ini membuktikan bahwa tinggi rendahnya besaran pembiayaan UMi PT. Pegadaian yang diberikan kepada pelaku UMKM tidak mempengaruhi perkembangan UMKM di Kota Palu.

Dari hasil perhitungan menggunakan rasio Revenue (Sales) Growth Rate untuk mengetahui omzet penjualan sebelum dan sesudah mendapatkan pembiayaan disimpulkan bahwa rata-rata pelaku UMKM yaitu 18 responden mengalami peningkatan penjualan $(60 \%)$, berkisar antara $24 \%$ 204\%. Sedangkan 4 responden mengalami penurunan omzet penjualan (13\%), berkisar antara $-33 \%--100 \%$ dan 8 orang tidak mengalami penurunan maupun peningkatan omzet penjualan atau tetap $(27 \%)$. Penggunaan bunga sewa modal atau bunga yang digunakan dalam pembiayaan UMi di pegadaian jelas tidak sesuai dengan prinsip-prinsip syariah, karena termasuk dalam riba dan merupakan perkara yang diharamkan dan dilarang oleh Alla swt.

\section{DAFTAR PUSTAKA}

Aprilia, Eka. “Pengaruh Produk Pembiayaan Mikro 75 iB Terhadap Perkembangan Usaha Kecil dan Menengah (UMKM) Pada Bank Syariah Kantor Cabang Tanjung Karang Periode 2010-2015", (skripsi: Universitas Islam Negeri Raden Intan Lampung, 2017)

Badan Litbang dan Diklat Kementerian Agama Republik Indonesia, "Tafsir Ringkas Al-Qur'an ALKarim (Tafsir Wajiz Jilid I, Bagian 1, 2016), Lajnah Pentashihan Mushaf Al-Quran, https:/ / pustakalajnah.kemenag.g o.id/detail/127, 129-130.

Maret 2021)

Chandra, Pudi E. Trik Sukses Menuju Sukses ; Yogyakarta: Grafika Indah, 2000

Dewan Syariah Nasional Majelis Ulama Indonesia. Fatwa Majelis Ulama Indonesia, MUI Nomor 1 Tahun 2004, Tentang Bunga (Interest/Fai' dah)

Dewan Syariah Nasional MUI, Fatwa DSN No: 68/DSN-MUI/III2008, Tentang Rahn Tasjiliy.

Ermawati, dkk. "Pengaruh Penggunaan Media Sosial Terhadap Keputusan Pembelian Kuota Internet Pada Mahasiswa Fakultas Ekonomi dan Bisnis Islam IAIN Palu," Jurnal Ilmu Ekonomi dan Bisnis Islam JIEBI Vol.2, No. 1 Tahun 2020, https://jurnaljiebi.org/index.php Ljiebi/article/view/22/17, 48, (24 Maret 2021)

Fitria, Ana. “Tinjauan Hukum Islam Terhadap Praktik Pemberian Kredit Modal Kerja Angsuran Sistem Gadai (KRASIDA) Bagi USaha Mikro di PT Pegadaian Cabang Jember", (Skripsi: IAIN Jember, 2015)

Irianto, Sigit, Widyarini Indriasti Wardani dan Anik Tyaswati, “Harmonizing Rules Micro Small and Medium Enterprises In The Era of The Pandemic Covid19 in Indonesia, European Journal of Molecular \& Clinical MedicineEJMCM, Vol.7 (September 2020)

Iqbal, Staff Kantor Pegadaian Deputy Bisnis Area Palu, Wawancara oleh peneliti di Kantor Pegadaian Deputy Bisnis Area Palu, 15 Desember 2020

Hafidah, Noor. "Kajian Prinsip Hukum Jaminan Syariah Dalam Kerangka Sistem 
HukumSyariah," Rechtidee 8.2.2013, https://journal.trunojoyo.ac.id/r echtidee/article/view/696, 6-7, (20 Februari 2021).

Jalil, A., \& Hamzah, S. A. (2020). PENGARUH BAGI HASIL DAN KEBUTUHAN MODAL TERHADAP MINAT UMKM MENGAJUKAN PEMBIAYAAN PADA LEMBAGA KEUANGAN SYARIAH DI KOTA PALU. Jurnal Ilmu Perbankan dan Keuangan Syariah, 2(2), 178-198.

Kasmir. Bank dan Lembaga Keuangan Lainnya, Jakarta: Raja Grafindo Persada, 2005

Kementerian Keuangan Republik Indonesia Direktorat Jenderal Perbendaharaan, Buku Saku Monitoring dan Evaluasi Pembiayaan Ultra Mikro (Direktorat Sistem Manajemen Investasi).

Kerjasama Lembaga Pengembangan Perbankan Indonesia (LPPI) dan Bank Indonesia, Profil Bisnis UMKM ; Jakarta: 2015

Malarangan , Hilal, dkk. "Analisis Tangoung Jawab Pegadaian Syariah Palu Plaza Terhadap Barang Jaminan yang Hilang dan Rusak'" Jurnal Ilmu Ekonomi dan Bisnis Islam - JIEBI Vol. 2 No. 1 Tahun 2020,

https://jurnaljiebi.org/index.php /jiebi/article/view/21/16, 18, (24 Maret 2021).

Malkan, M., Kurniawan, I., Nurdin, N., \& Noval, N. (2021). Pengaruh Pengetahuan Tentang Pasar Modal Syariah Terhadap Minat Investasi Saham di Pasar Modal Syariah Jurnal Ilmu Perbankan dan Keuangan Syariah, 3(1), 57-73.

Marzuki, M., \& Nurdin, N. (2020). The Influence of Halal Product
Expectation, Social Environment, and Fiqih Knowledge on Intention to Use Shariah Financial Technology Products. International Journal of Innovation, Creativity and Change, 13(1), 171193.

Ningsi, N. J. dan Hasan, H. Tinjauan Hukum Islam Terhadap Bunga Dalam Pembiayaan Konvensional dan Margin Dalam Pembiayaan, Iqtishaduna: Jurnal Ilmiah Mahasiswa Hukum Ekonomi Syari'ah, Vol. 2, (2020), 35. http:/ /103.55.216.56/index.php/i qtishaduna/article/view/15137, 03 Maret 2021

Nurdin, N., Azizah, W. N., \& Rusli, R. (2020).

Pengaruh

Pengetahuan,Kemudahan dan Risiko Terhadap Minat Bertransaksi Menggunakan Finansial Technology (Fintech) Pada Mahasiswa Institut Agama Islam Negeri (IAIN) Palu Jurnal Ilmu Perbankan dan Keuangan Syariah, 2(2), 199-222.

Nurdin, N., Ningrum, R., Bachmid, S., \& Jalil, A. (2021). Pengaruh Manfaat, Kepercayaan dan Kemudahan Penggunaan Terhadap Minat Nasabah Menggunakan Mobile Banking di Bank Mega Syariah Cabang Palu Jurnal Ilmu Perbankan dan Keuangan Syariah, 3(1), 30-45.

Nurfitria, Nissa dan Retno Hidayati, "Analisis Perbedaan Omzet Penjualan Berdasarkan Jenis Hajatan dan Waktu (Studi Pada Catering Sonokembang Semarang)",http:/ / eprints.undip. ac.id/29369/1/jurnal_omzet_penj ualan.pdf (02 November 2020)

Nurrohmah, Isniani. "Analisis Perkembangan Usaha Mikro, 
Kecil dan Menengah Sebelum dan Sesudah Menerima Pembiayaan Musyarakah pada Koperasi Jasa Keuangan Syariah BMT (Studi Kasus: BMT Beringharjo Yogyakarta)", (Skripsi Program Sarjana Pendidikan Ekonomi Fakultas Ekonomi Universitas Negeri Yogyakarta, 2015)Otoritas Jasa Keuangan. Peraturan Otoritas Jasa Keuangan Nomor 11/POJK.03/2015, Tentang Ketentuan Kehati-hatian dalam Rangka Stimulus Perekonomian Nasioanal Bagi Bank Umum Pasal 1.

Poermawarman. "Pengaruh Return On Asset, Sales Growth, Asset Growth, Cash Flow, Dan Likuiditas Terhadap Dividend Payout Ratio Perusahaan Perbankan Di Bursa Efek Indonesia Tahun 2009-2013", Jurnal Jom FEKON Vol. 2 No. (1 Februari 2015) https://media.neliti.com/media/ publications/33870-ID-pengaruhreturn-on-asset-sales-growthasset-growth-cash-flow-danlikuiditas-terh.pdf (17 Februari 2021).

Prawirokusumo,

Soehart.o

Kewirausahaan dan Manajemen Usaha Kecil, Edis1; Jogjakarta: BPFE, 2010

--------, Peraturan Menteri Keuangan Nomor 95/PMK.05/2018, Tentang Pembiayaan Ultra Mikro Pasal 1.

PT. Pegadaian, Pinjaman Usaha, Situs Resmi Pegadaian, diakses melalui https:/ / www.pegadaian.co.id

Republik Indonesia, Undang-undang Nomor 20 Tahun 2008, Tentang Usaha Mikro, Kecil dan Menengah Pasal 1
-Undang-undang No. 42 Tahun 1999, Tentang Jaminan Fidusia Pasal 1. Republik Indonesia, Qur'an KEMENAG, https:/ / quran.kemenag.go.id/sur a/2, (25 Februari 2021)

Rosita,Rahmi. "Pengaruh Pandemi Covid-19 Terhadap UMKM, Jurnal Lentera Bisnis-JRLAB, Vol. 2 Nomor 2 (November 2020),

Rivai, Veithzal dan Arviyan Arivin. Islamic Banking, Jakarta: PT. Bumi Aksara, 2010

Rusli, R., \& Nurdin, N. (2021). Understanding Indonesia millennia Ulama online knowledge acquisition and use in daily fatwa making habits. Education and Information Technologies.

https://doi.org/10.1007/s10639021-10779-7

Sari, Maya. "Pengaruh Pembiayaan Mudharabah Terhadap Perkembangan Usaha Mikro, Kecil dan Menengah (UMKM) BMT Sepakat Tanjung Karat Barat", (Skripsi: Universitas Islam Negeri Intan Lampung, 2019

Sholeh, Muhammad. Upaya Pengembangan Usaha Kecil dan Menengah; Jakarta: Rajagrafindo Persada, 2008

Qur'an KEMENAG, https:/ / quran.kemenag.go.id/sur a/2, (25 Februari 2021)

Sofyan,A. Syathir. "Hukum Gadai Islam dan Prakteknya di Sulawesi Selatan", Bilancia: Jurnal Studi Ilmu Syariah dan Hukum IAIN Palu, vol. 13 No. 2 (July-Desember 2019)

Sugiyono. Metode Penelitian ; Bandung: ALFABETA,2018 